\section{BRÈVES}

$\mathrm{Rb}$ [1]. En revanche, l'expression de l'ADNc $\mathrm{Rb}$ dans des cellules tumorales sans altération de l'anti-oncogène endogène $\mathrm{Rb}$ ne modifia pas le potentiel prolifératif de ces cellules. Ces résultats sont très importants car, sur le plan théorique, ils valident la notion de gène «suppresseur de cancer » et, sur le plan pratique, démontrent la faisabilité d'une stratégie de "guérison» de la cellule cancéreuse par apport d'une substance ou d'une information génétique antiproliférative.

[1. Huang HJS, et al. Science 1988 ; $242: 1563-6$.

L'apport alimentaire de sel détermine l'hypertrophie du ventricule gauche chez l'hypertendu. Chez 42 hypertendus essentiels, Schmieder et al. [1] ont analysé les corrélations entre le degré d'hypertrophie ventriculaire gauche (mesurée par échographie) et différentes variables : l'épaisseur de la paroi du ventricule gauche est fortement reliée à l'apport alimentaire en sel (apprécié par l'excrétion urinaire quotidienne de sodium), alors que d'autres paramètres comme la pression artérielle diastolique, l'hématocrite, l'adrénaline ou la rénine plasmatique ont peu ou pas d'influence. Des observations antérieures ont montré que la restriction stricte en sel peut diminuer la masse ventriculaire gauche chez l'hypertendu. Ces résultats concordent parfaitement avec ceux du groupe d'A Mimran (présentés aux Journées d'Hypertension artérielle, 1988, sous presse): chez 41 hypertendus, la masse ventriculaire gauche est positivement corrélée à l'excrétion sodée urinaire. Les mécanismes qui relient l'apport alimentaire de sel et la masse ventriculaire gauche chez l'hypertendu restent mal connus.

[1. Schmieder RE, et al. Circulation $1988 ; 78: 951-6$.

$\mathrm{m} / \mathrm{s} n^{\circ} 3$ vol. 5 , mars 89

\title{
Système rénine-angiotensine et hypertension artérielle (suite)
}

Récemment, le clonage moléculaire du gène de la rénine humaine et de son ADN complémentaire, grâce aux techniques issues de la biologie moléculaire, a permis d'acquérir de nouvelles connaissances sur la régulation de l'expression de ce gène, et sur la biosynthèse et la sécrétion de la rénine. Ces progrès sont résumés dans l'article de synthèse de Dzau et al. [1] Le gène de la rénine a une taille d'environ 12,5 kb (kilobases). Chez l'homme, il comporte dix exons et neuf introns (alors que chez le rat et la souris, il ne contient que neuf exons). L'exon supplémentaire trouvé chez l'homme (exon 5A) code seulement pour trois acides aminés et sa fonction est mal connue. Entre les différentes espèces étudiées, il y a une grande homologie de séquence dans la région bordante 5'. Dans cette région du gène humain, deux TATA boxes ont été localisées; ces séquences sont bien conservées dans toutes les espèces et représentent probablement des éléments du promoteur du gène de rénine. Chez les rongeurs, la déplétion sodée, la stimulation $\beta$-adrénergique ou l'ischémie rénale augmentent les taux d'ARN messager de la rénine dans le rein ; en revanche, les androgènes et les oestrogènes n'augmentent pas l'ARN messager rénal (alors que l'expression est accrue dans d'autres tissus). En l'absence de modèle cellulaire ex vivo reproduisant la production rénale de rénine, c'est la technique des souris transgéniques qui devrait permettre de préciser les éléments d'ADN responsables de ces différentes réponses du gène à ses effecteurs.

La plupart des protéines importantes du système rénine-angiotensine ont été aujourd'hui clonées. Soubrier et al. [2] viennent d'effectuer le clonage moléculaire de l'ADNc codant pour l'enzyme de conversion humaine (responsable de la transformation de l'angiotensine I en angiotensine II). Cette enzyme a deux sites catalytiques potentiels mais seul l'un des deux domaines doit être actif puisque un seul atome de zinc se lie à la molécule d'enzyme de conversion. La séquence de l'ADN complémentaire de l'enzyme suggère que le gène résulte d'une duplication. Il existe probablement un seul gène par génome haploïde humain, codant pour les différentes formes d'enzyme de conversion: l'enzyme plasmatique dériverait de l'enzyme présente dans les cellules vasculaires endothéliales ; en revanche, l'enzyme testiculaire est synthétisée sous la forme d'une chaîne peptidique plus courte. L'ARN messager de l'enzyme testiculaire $(3 \mathrm{~kb})$ et l'ARNm de l'enzyme endothéliale $(4,3 \mathrm{~kb})$ proviendraient d'un épissage différentiel du transcrit du gène.

Ces progrès ouvrent la voie à l'étude des mécanismes génétiques qui contrôlent le système rénine-angiotensine et qui pourraient être à l'origine des hypertensions artérielles familiales [3].

J.-P.-G.

1. Dzau VJ, Burt DW, Pratt RE. Molecular biology of the renin-angiotensin system. Am J Physiol 1988 ; 255 : F563-73.

2. Soubrier F, Alhenc-Gelas F, Hubert C, $e$ al. Two putative active centers in human angiotensin I-converting enzyme revealed by molecular cloning. Proc Natl Acad Sci USA 1988 ; 85 : 9386-90.

3. Corvol P, Jeunemaître X, Plouin PF, Cambien F, Soubrier F. Approche de l'hypertension artérielle familiale par la génétique moléculaire. Actualités Néphrologiques de l'Hôpital Necker. Paris: Flammarion, 1989 (sous presse).
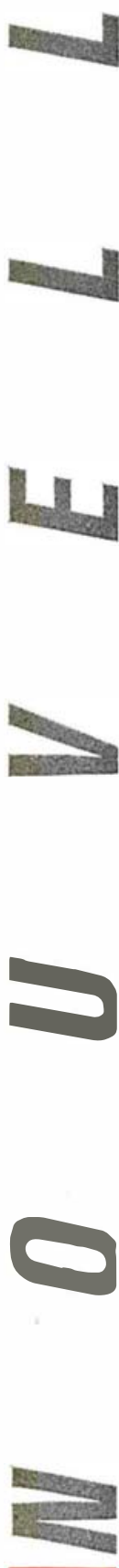